\title{
"The Event of Place": Teacher Candidates' Experiences of a Northern Practicum
}

\author{
Melanie D. Janzen \\ University of Manitoba
}

\begin{abstract}
Author Note
I would like to thank the University of Manitoba Undergraduate Research Award for the funding that supported this research. I would also like to thank Caitlyn Arnould for her assistance with this research project.
\end{abstract}

\begin{abstract}
Teacher education programs in Canada-by the nature of their geographic locations and composition of their faculty and students - remain largely urban centric in their values and programs. Yet, teacher education programs are responsible for preparing teachers for rural, remote, and northern teaching experiences. In this study, I explore the experiences of teacher candidates who participated in a northern practicum option developed at a Western Canadian teacher education program. The purpose of this research is to examine teacher candidates' experiences of the northern practicum option in order to inform our northern practicum option, as well as to contribute to the development of other northern practicum offerings in Canadian teacher education programs. Drawing on place-conscious theorizing, I explore the ways in which the northern practicum experiences have the potential to disrupt settler-colonial narratives, to develop understandings of place-based curriculum and pedagogies, and to support democratic and ethical approaches to education.
\end{abstract}

Keywords: Northern Canada; practicum; teacher education; qualitative research; placeconsciousness
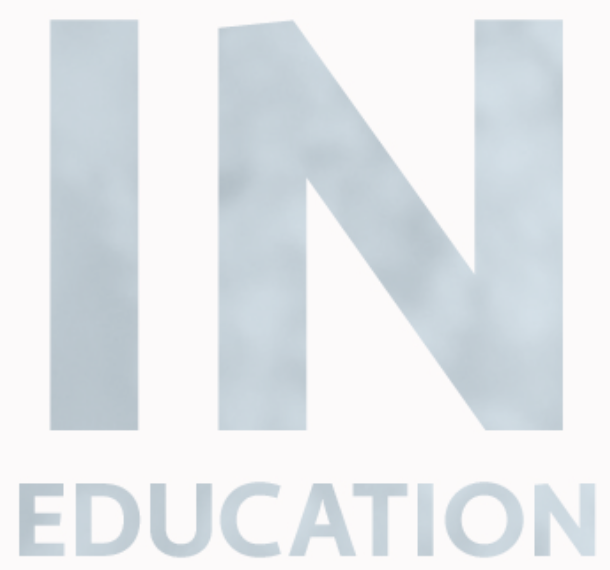


\section{“The Event of Place": Teacher Candidates' Experiences of a Northern Practicum}

What is special about place is not some romance of a pre-given collective identity or of the eternity of the hills. Rather, what is special about place is precisely that thrown togetherness, the unavoidable challenge of negotiating a here-and-now (itself drawing on a history and a geography of thens and theres); and a negotiation which must take place within and between both human and nonhuman. This in no way denies a sense of wonder: what could be more stirring than walking the high fells in the knowledge of the history and the geography that has made them here today. This is the event of place. (Tuck \& McKenzie, 2015, p. 140) ${ }^{1}$

Canada is a geographically vast nation with the majority of its population found along the southern border, while Northern Canada remains on the literal and figurative margins of Canada, remote in the psyche of urban Canadians. Subsequently, Canadian teacher education programs often exist in urban centres and remain a vastly urban-centric endeavour (White \& Reid, 2008). It is not surprising then that Northern Canada is also a geographic region where teacher retention is difficult and attrition is high (Kutsyuruba \& Tregunna, 2014); and when teachers leave, students are negatively affected both academically and emotionally (Day \& Gu, 2010; Loeb, DarlingHammond \& Luczak, 2005; Mueller, Carr-Stewart, Steeves, \& Marshall, 2011; White \& Reid, 2008). Yet, Canada's North is an important geographic, historic, social and cultural part of Canada and faculties of education and could be an important venue for addressing issues of marginality by contributing to improved teacher experiences in and understandings of the North. Providing teacher candidates' with exposure to northern communities through their practicum would broaden teacher candidates' experiences and could lead to less attrition for those teacher candidates who end up teaching in the North.

Practicums serve as a means for teacher candidates to gain experience with the everyday responsibilities of classroom life within the broader context of a particular community; to develop working relationships with administration and colleagues; and to learn to work within mandated structures and policies (Danyluk \& Sheppard, 2015b; Jones, 2011). For teacher candidates, the practicum is often the most valued portion of their bachelor of education programs (Danyluk \& Sheppard, 2015a; Smits, 2010) and is considered integral to the their preparation in regards to making connections and networking, gaining exposure and experience, and expanding their career opportunities (Jones, 2011). Creating northern practicum options for teacher candidates could help to minimize the marginalization of the North in the minds of (future) educators and could contribute to improved understandings of the North, and thus, support teacher candidates in considering teaching jobs in the North. Ultimately, northern practicum options in Canadian teacher education programs could improve the quality of the teaching force in the North - and thus, the quality of northern education - for those who live in northern and remote places of this Country. Although the resources required for creating and maintaining such practicum options pose a challenge for faculties of education (Danyluk \& Sheppard, 2015b), this challenge does not diminish the importance and ethical imperative to do so.

Although there has been some research conducted on the experiences of in-service teachers in northern Canadian settings, there is very little research regarding the experiences of preservice teachers in northern settings. The purpose of this research project was to explore and contribute to these currently limited discussions. Specifically, I considered how teacher candidates experience and understand a northern practicum with the hopes of informing teacher education 
programs in regards to northern practicum options, as well contributing to the broader discussions in Canadian teacher education. Examining these experiences can inform teacher education programs in navigating the logistics and in considering their responsibilities in offering northern practicum options. In this research, I interviewed four teacher candidates who opted to participate in our Faculty's newly created northern practicum option. Drawing on place-conscious theorizing, I explored the ways in which the northern practicum option had the potential to disrupt settlercolonial narratives, to develop understandings of place-based curriculum and pedagogies, and to support democratic and ethical approaches to education.

\section{Theoretical Framework: Place-Conscious Education}

Teacher education programs are most often designed with little attention to the geographic and sociologic diversity in which they are located (Green \& Reid, 2004) and tend to privilege urbancentric perspectives (White \& Reid, 2008). However, Gruenewald (2003b) argues that place matters in education, stating that by supporting a "generic education for "anywhere," we risk promoting an education for nowhere (p. 646). In other words, "place teaches us about the world" (Gruenewald, 2003b, p. 621) and concomitantly, place shapes us and informs our identities. Drawing from critical theory and a critical pedagogy of place, Gruenewald (2003a) theorizes what he calls, place-consciousness. Specifically, he illustrates the interconnections between critical pedagogy, with its focus on geographic contexts, and place-based education, with its emphasis on localized social action, in order to foster "critical social and ecological concerns into one's understanding of place, and the role of places in education" (Gruenewald, 2003a, p. 9). In other words, whereas place-based education sought to centre the local, critical place-consciousness maintains a concern for the local and those who live there, but also holds a critical eye toward global issues and the effect these will have on the local.

In his theorizing, Gruenewald (2003b) makes strong connections between place, ecosystems, and social landscapes while exploring how mainstream education serves to oppress these connections. Instead, he argues that place-based education is critical in reconnecting school and community, and fosters values of democracy, interdependence, criticality, ethics (Gruenewald \& Smith, 2008). Gruenewald (2003b) suggests that place-conscious education is a more considerate and equitable pedagogy that values diverse needs and strengths and can realize the genuine intent of education. Gruenewald (2003a) seeks to challenge educational traditions that aim to standardize experiences for students from diverse cultural and geographical backgrounds by promoting the development and use of a critical pedagogy of place. Researchers and educators, then, must consider the social and ecological contexts and dimensions in which they are situated, "making a place for the cultural, political, economic, and ecological dynamics of places" (Gruenewald, 2008, p. 10). The overarching purpose is an attempt at "reeducating [sic] people in the art of living well were they are" (Orr, 1992, p. 130). This, of course, is greater than simply experiencing different places. Place-based education is not culturally or politically neutral (Tuck, McKenzie, \& McCoy, 2014), and therefore, requires an attuned and critical engagement.

\section{Literature Review}

Geographically speaking, Northern Canada refers to the territories (specifically, Yukon, Northwest

Territories, and Nunavut) as well as those areas past the limit of isolated permafrost in British Columbia, Alberta, Saskatchewan, Manitoba, Ontario, Quebec, and Newfoundland and Labrador. Significantly, almost two-thirds of Canada's landmass is located in the North. In Canada, "the 
North" is often uniquely characterized as representing both the places and the peoples living there. Many communities in Canada's North are often isolated to some degree and are home to significant Indigenous populous, namely First Nations, Métis, and Inuit. Given these dimensions, I recognize the North as a geographic region of Canada that contains unique cultural, historical, and social attributes. Although I will use the term "the North," I do not mean to imply that the various places in the North are homogenous; rather, I recognize the diversity of the places in the North and the people who live there.

In the literature search, I focused specifically on the North rather than rural Canada in order to seek studies that were distinctly concerned with this region. Additionally, although similar themes arise (such as those related to teacher attraction and retention) in regards to teaching in remote regions of other countries (for example, in Australia), I sought research related directly to teachers' experiences in Canada's North. The initial review found very few Canadian studies that considered teacher candidates' experiences in northern practicums (Danyluk \& Sheppard, 2015b; Winter \& McEachern, 1999), and so, I expanded the search to include literature that considered in-service teachers' experiences in the North. To be clear, I am not assuming that the experiences of in-service and preservice teachers are the same. However, because of the limited literature available for preservice teachers' experiences in Northern Canada, I hoped that the literature on in-service teachers' experiences in the North might provide some insight into the issues that teachers do experience in regards to place. Therefore, this literature review includes preservice and in-service teachers' experiences in Northern Canada, with an eye to provide some insight on the common themes and issues of northern teaching experiences.

\section{Teacher Employment, Promotion, and Retention}

From the literature on teachers' experiences in the North, it becomes clear that a key focus in the research is related to promotion, retention, and attrition of teachers in northern schools. This line of research is a response to the concern that schools in the North are often subject to high teacher turnover and attrition rates (Kutsyuruba \& Tregunna, 2014). Thus, many studies sought to respond to the issue of teacher attrition specifically by considering aspects of the promotion of employment as well as retention of teachers in Northern communities. For example, Janzen and Cranston (2015) sought to explore in-service teachers' motivations and experiences in order to consider factors that attracted and retained teachers in northern communities, which included competitive salaries and benefits, subsidized teacher housing, opportunities for partner employment, and permanent contract offers. Similarly, through an adaptation of Maslow's basic human needs hierarchy, Williment (2003) explored how physiological, esteem, safety, belongingness, and self-actualization needs affect the retention or attrition of teachers in Northern Lights School Division in Saskatchewan. Promotion and retention was also considered from an administrative perspective by Brandon (2015), who sought to analyze how the government and school divisions in Alberta are working to better prepare and retain teachers for northern and remote communities, and illustrates the innovative approaches to attracting, preparing, supporting, and retaining teachers in northern and remote Alberta contexts.

Other factors positively correlated to issues of retention and attrition include preparation time and new teacher mentorship (Williment, 2003). Additionally, it was found that factors such as distance from relatives and friends, as well as a lack of certain amenities could impact teacher attrition (Janzen, 2015; Williment, 2003). Cross-cultural barriers may exist that are difficult to transcend (Goulet, 2001; Harper, 2000). Williment (2003) added that a perceived lack of parental 
support concerning teachers' work in some instances and professional development opportunities may also influence teacher retention and attrition in the North.

\section{Teachers' Expectations and Experiences}

Some research noted the "clashes" between teachers' expectations and their experiences. With no prior experience, new teachers in northern communities often had only their preconceptions to guide them. Often, these preconceptions were based on learned and imagined stereotypes, for example, that northern communities tended to be represented as poor and deprived (Danyluk \& Sheppard, 2015a). However, though northern communities may earn less on a national scale, some communities are quite affluent and prosperous (Danyluk \& Sheppard, 2015a). With limited experience in the North and narrow preconceptions, teachers new to these communities were likely to experience a clash between reality and expectation (Oskineegish \& Berger, 2013); or what others characterized as "culture shock" (Harper, 2000). These clashes became the sources of job dissatisfaction and often led to attrition. It was suggested that new teachers would benefit from induction programs (Williment, 2003), longer orientation periods, and assignments to sponsor families to aid in cultural adjustment (Multamaki, 2008).

Not surprisingly, the research indicated that the relationships teacher candidates develop during their time in the North influenced the quality of their experiences (Brandon, 2015). Although relationships are a large part of creating responsive dynamics in any educational setting, the unique nature of the North made the quality of these relationships even more potent and affected teachers' stress and job satisfaction (Klassen, Foster, Rajani, \& Bowman, 2009). Due to the physical proximity of people living in small communities, the quality of relationships teachers developed with students, parents, and community members was an important factor in the quality of northern teaching experiences, underscoring the importance of developing positive relationships within these communities. Building positive relationships with community members involved taking risks (or putting oneself "out there") (Danyluk \& Sheppard, 2015a), for example, by coaching a sports team, taking language courses, or volunteering in community events. Oskineegish and Berger (2013) connected relationship building with developing cultural competencies.

However, community engagement comes with the additional dimension of being cognizant of the appropriate limits for such involvement. Unlike urban centres, in small northern communities, the school and community are not two isolated places (Oskineegish \& Berger, 2013). Therefore, in order to succeed it was important to understand that, "how educators interact in either place can directly affect their relationships outside of the school as well as their instructional abilities within the classroom" (Oskineegish \& Berger, 2013, p. 120). Therefore, being involved in community affairs required sensitivity and sometimes felt like a "balancing act" for teachers, requiring some experience and considerable effort especially in being sensitive to community politics (Danyluk \& Sheppard, 2015a). Given these community demands and dynamics, teachers sometimes felt as though they worked around the clock in northern communities (Danyluk \& Sheppard, 2015b), especially given the additional demands placed on new teachers (Williment, 2003).

Some research highlighted the difficulty that teachers had in developing relationships. In their study, Danyluk and Sheppard (2015b) found that beginning teachers were surprised at the perceived difficulty they had in building relationships with parents, who teachers felt were 
sometimes resistant to engaging with them. Some of this perceived resistance stemmed from parents' mistrust of schools and their fear that education may lead their children to seek opportunities outside of the community (Danyluk \& Sheppard, 2015b). Given the disproportionate numbers of missing and murdered Indigenous women and girls (Royal Canadian Mounted Police, 2014) and the often life-threatening experiences of students who must travel away to attend school (Talaga, 2017), parents' fears are a reality for those with children who might want to move away for educational opportunities. Additionally, some community members were resistant to putting effort into developing relationships with newcomer teachers, sensing that these teachers were only working for a "quick buck" (Danyluk \& Sheppard, 2015a). This research illustrates the importance of understanding the impact of enduring colonialism and the subsequent mistrust that might exist in northern communities, shaping parents' and communities' perceptions of education (Danyluk \& Sheppard, 2015a; Winter \& McEachern, 1999).

The enduring effects of residential schools and other colonial practices adds to the layers of complexity influencing teachers' relationships with students and community members. Danyluk and Sheppard (2015a) noted, "All teachers encounter students with complicated home lives but in some isolated communities the cycle of poverty and aftermath of residential schools has wreaked havoc on families" (p. 236). What makes confronting these realities even more difficult is the fact that teacher candidates are trained in and for a system that embodies colonial practices (Battiste, 1998; Danyluk \& Sheppard, 2015a). In practicum and beyond, the tools used to work against the effects of colonialism have roots in colonial thought, and so the inclusion of Indigenous history (Danyluk \& Sheppard, 2015b) with an emphasis on colonialism (Oskineegish \& Berger, 2013) is an important facet of teacher education programs.

Additionally, some researchers have recognized the potentially conflicting paradigms within education; specifically, that teacher candidates' implicit endorsement of education may exist in sharp contrast to Indigenous peoples' (past and current) experiences of education as a colonial project. Therefore, what deemed worthwhile in a teacher education program may in fact conflict with a particular community's experiences, expectations, and priorities (Danyluk \& Sheppard, 2015b; Harper, 2000). This potential conflict required an understanding and respect for the contextual nature of education, including being cognizant of one's own identities when entering northern communities (Danyluk \& Sheppard, 2015b). Some teachers new to northern communities were surprised by the social dynamics in the communities (Danyluk \& Sheppard, 2015b), and commented on the feeling of "suddenly being white" (Harper, 2000), illustrating the importance understanding privilege in the context of sociohistorical realties, including the impact of colonization and power relationships within education (Goulet, 2001).

The research also indicated the various ways in which teachers often felt under supported financially and pedagogically, for example, that their efforts to incorporate culturally relevant materials into their practice were impeded by a lack of resources (Danyluk \& Sheppard, 2015b), which was a factor in teachers resigning (Williment, 2003). Teachers also felt ill-prepared to support students who were learning English as an additional language (Danyluk \& Sheppard, 2015a; 2015b; Harper, 2000). Further, teachers felt overwhelmed by the multi-age classrooms often found in Northern communities with their vast curricular ranges and instructional levels (Danyluk \& Sheppard, 2015a; Multamaki, 2008).

Newcomers to northern communities also often experienced social and cultural isolation, sometimes feeling unprepared for life in remote and isolated communities (Danyluk \& Sheppard, 
2015b; Harper, 2000; Multamaki, 2008). Some teachers felt limited by the lack of local amenities, while others missed their support networks of family and friends (Danyluk \& Sheppard, 2015b; Multamaki, 2008; Williment, 2003). Some prospective teachers expressed concerns about the potential lack of employment for their partners (Danyluk \& Sheppard, 2015a; Williment, 2003) and the limited opportunities available for their children (Janzen, 2015).

While teacher attrition can be higher in northern communities, there is some research that shows teachers' satisfaction with their work and life in the North (Danyluk \& Sheppard, 2015a; 2015b; Janzen, 2015; Williment, 2003), and illustrates their enjoyment being away from urban living (Williment, 2003).

\section{Preparing Teachers to Work in the North}

Some studies in my search explored ways to support the promotion and retention of teachers in the North. For example, Multamaki (2008) studied teacher candidates' perceptions of working in the North in order to determine what governments and teacher education programs could do to attract teachers to the North. Her findings suggest that teacher education course content and professors' views of the North influenced teacher candidates' perspectives on teaching in the North. Oskineegish and Berger (2013) sought to support and prepare "non-Native teachers" in their work in First Nations' communities in Northern Ontario, revealing the importance of supporting teachers' understandings of their roles as teachers and as visitors in the communities, and of developing reciprocal relationships with students, colleagues, families, and community members. Similarly, Harper's (2000) research argues for more intensive preservice and in-service teacher education programs that work to "organize and clarify" (p. 4) relationships between teachers and the communities, and have "Native" education courses to better prepare educators for work in the North.

\section{Teacher Education Programs and Northern Practicums}

Some of the literature made an imperative connection between teacher training programs and teacher candidates' willingness and preparedness to teach in the North. For example, Brandon (2015) argued that, teacher education programs play a vital role in attracting preparing, supporting, and retaining "excellent teachers" in northern communities. The aspiration to better prepare teacher candidates for northern experiences is also reflected in The Association of Canadian Deans of Education (2010) Accord on Indigenous Education, which calls for, "opportunities within all teacher education programs for candidates to have authentic experiences in a variety of Indigenous learning settings, whether urban, rural, remote, band-funded, or provincially funded" (p. 8). This objective makes an overt claim to the importance and responsibility of teacher education programs to better support teachers in their exposure and preparedness to teach in a variety of Indigenous settings, including in northern communities.

Danyluk and Sheppard (2015a; 2015b) found that embedding indigenous components into the Bachelor of Education program at Laurentian University had positive effects on the number of students who pursued positions in Indigenous communities. Graduates agreed that more focus should be placed on these communities while in teacher education programs, while others suggested a northern practicum should be required (Danyluk \& Sheppard, 2015a; 2015b). Meanwhile, Harper (2000) suggested that, "instead of preparing individuals for a generic school, teacher education programs might focus on the need to prepare individuals for specific schools and communities (p. 155)." Notably, the literature also indicates that there are benefits to faculty 
members and programs more broadly, in that attention to the importance and value of northern exposure and experience within the Faculty encouraged faculty action (Danyluk \& Sheppard, $2015 \mathrm{a} ; 2015 \mathrm{~b}$ ). These studies suggest that teacher education programs with northern practicum experiences can have positive influences on teacher candidates' experiences and understandings of teaching and living in the North.

It is important to note that most studies pointed to the differences in northern living from deficit perspectives. For example, the research sometimes implicitly considered isolation as a negative experience even though we live in a culture rife with opportunities for "get-ways" and "retreats." This again underscores the urban-centric perspectives of teacher education programs and research related to teacher education and the North. In addition, the literature in Canada on teacher candidates' experiences in the North is focused primarily on issues of employment promotion and teacher retention. Although job preparation is an important aspect of teacher experiences in northern settings, there is an imperative to consider the importance of northern practicum in regards to place conscious education, where there is a recognition of the diversity and strengths of these specific cultural and geographic contexts in order to engage teacher candidates' in their development of a critical pedagogy of place (Gruenewald, 2003a). Finally, in Canada, (re)considering the relationship between teacher education and northern communities is of particular importance given the geographic and relational divides between southern communities (predominantly non-Indigenous) and northern communities (often Indigenous). It is our responsibility as educators, teacher educators, and educational researchers to respond to the Truth and Reconciliation Commission's (2015) Calls to Action in order to improve the educational inequalities for children on reserve and in northern communities. Reconfiguring teacher education programs around place- consciousness and improving teacher candidates' access to and experience in northern practicums are ways in which to begin to address inequities for children's educational experiences on reserves and in the North.

\section{Methodology}

This qualitative study aimed to elicit the understandings and experiences of former teacher candidates who participated in a northern practicum experience in a faculty of education in a Western Canadian province. I conducted phenomenological interviews with four graduates from the Bachelor of Education program who had participated in a northern practicum option. Three of the interviews took place in person, while one participate responded by email due to distance. Although email is a relatively new mode of conducting interviews, research indicates that email can be a useful mode of eliciting narratives allowing for ample reflections on experiences (James, 2007). The interviews were conducted using semi-structured interview protocol which was comprised of a series of questions and sub-questions which sought to solicit various aspects of participants' experiences of the northern practicum. The protocol was provided to participants in advance of the interview and included questions about their reasons for wanting to participate, considerations in preparing to travel to the North, stories of expectations and experiences of the school and of the community, and how the experienced informed their understandings of being a teacher.

The in-person interviews were audio recorded and transcribed. Using Moustakas' (1994) (see also Creswell \& Poth, 2018; Groenewald, 2004) approach to data analysis, I read and re-read the transcripts, sought out significant statements, and then grouped these statements into themes. I then wrote narrative descriptions of both what the participants experienced and how these 
experiences occurred (Moustakas, 1994). Finally, through numerous re-readings and revisions, I created composite narratives, each representing a resonant theme pervasive in the experiences in an attempt to illustrate the essence of the experiences (Creswell \& Poth, 2018). The composite narratives reflect thematic portrayals of experiences from across the interviews, yet also attempted to maintain individual uniqueness of participants' experiences (Groenewald, 2004) by maintaining the participants' language, tone and intentions. My analytic process resulted in three different composite narratives that aimed to represent salient themes that arose in the teacher candidates' experiences of the northern practicum. Importantly, in eliciting the essence of these experiences, I was not attempting to articulate a "truth" or determine if particular events actually happened. Rather, I was seeking to represent the lived experiences of the participants, and then to put these experiences into conversation with place-conscious theory. My aim is to better understand teacher candidates' experiences in the North and what teacher education programs might learn from these experiences.

\section{Teacher Candidates' Experiences of the Northern Practicum Placements}

What follows are excerpts from the composite narratives, each of which represents a resonant theme from the participants' experiences. Although I have attempted to maintain the participants' language, word choices, and tone, it is important to read these as narratives within, and reflective of, greater systemic, structural, and settler-colonial discourses, not simply reflections of individual orientations and perspectives. Such discourses constitute knowledge and construct our social realities, thus normalizing particular understandings (Foucault, 1972/2010). Thus, while reading, it is important to consider these narratives within their greater discursive contexts, for example, to discern the discourses of settler-colonialism, of the "good" teacher, and of "good" teaching.

\section{James: Exploration and Discovery}

James grew up in a small, rural prairie community, and after high school, made his way through the western provinces - Saskatchewan, Alberta, and British Columbia-working in the oil industry. Now in a faculty of education, and finding the international practicum option cancelled, he decided that the northern practicum was his next best option. After all, he had never been that far north before-it remained undiscovered. Not only did James feel that participating in a northern practicum would set him apart from his peers, and perhaps, open doors for employment opportunities in the future, but also, he felt it was an incredible opportunity to discover a different part of the province. He described how the anticipation mounted as the teacher candidates prepared to leave. James's classmates were asking him lots of questions, figuring that he'd be dealing with some pretty crazy stuff, but James was anxious to just get there already and to find out if the stigma was actually true. James was ready to get some answers.

James was seeking adventure. Having previously traveled north for work and pursuing international adventures, he seems fearless and enthusiastic, reflective of many of our teacher candidates' youthful and energetic natures. We see that James was eager to "get there," anxious to respond to all those who "had been talking about it" and "asking questions." James, keen to supply answers to his peer group, was impatiently anticipating his arrival. In his narrative, we hear an explorer eager to set out on his journey. To some extent, James' eagerness might be considered important and admirable attributes of new teacher candidates. However, James might also be considered an adventurer with little sense of place, lacking knowledge of the social and historic realities of where he was going and of the rich culture and community that he would be 
experiencing. Arguably, his sense of adventure seemed to be guided by a naïve sense of voyeurism and curiosity about the "crazy stuff" he imagined having to confront, and underpinned by stereotypes of poverty and inadequacy.

Tuck and Yang's (2014) theorizing of settler-colonialism is useful in reading James' narrative. Specifically, Tuck and Yang (2014) describe the settler as seeking land and as constructed as "superior and most normal" (p. 812). Although there might not be an overt intention in James" enthusiasm to "own" the land, he seemingly acts as though it is there for the taking, and that it is his entitled right to do so. This is not a criticism of James himself, but rather reflects the effects and ubiquitousness of settler-colonial discourses. Settler-colonial perspectives would be unconcerned with those already there, except perhaps in the voyeuristic sense. James says he wants to "get there" so he can "discover" the place, as if others have not already done so; and to be able to take this experience as an accomplishment and an achievement that other teacher candidates would not have had. Through a settler-colonial lens, James's discourse of "discovery" is reflective of an implicit imperialism and "othering." Again, these perspectives cannot simply be attributed to the "fault" of James, but rather reflect the settler-discourses that inform and constitute James' understandings.

It is also important to note the personal attributes of risk-taking and the adventure-seeking attitude of the teacher candidates, in that these might signal openness and a desire to learn. These attributes could indeed be beneficial attributes of future teachers. Thus, James's narrative might serve as a cautionary tale for teacher educators; specifically, just because Northern practicums are created and teacher candidates are excited to participate, does not mean that teacher candidates have a sense of how to engage in such experiences. Teacher educators must be conscious of the risks of fostering "edu-tourism," where education and tourism are melded and invoke missionary tours or heroic journeys by those of the dominant groups setting out to "help" or "save" the "other." Instead, helping teacher candidates understand place-consciousness would foster a mindfulness of the colonial impulse of schooling (Seawright, 2014, p. 17), account for settler traditions and settlercolonial perspectives, and instill a more critical and informed standpoint of the teacher candidates. As Dwayne Donald (2011) suggests, "When connections and differences are acknowledged simultaneously, then a relational tension arises based on how the entities, worldviews and knowledge systems are perceived to interface with one another" (p. 105). What might teacher candidates recognize about their own identities and privileges, their desires in going north, and their hopes for their experience if they could engage in critical conversations about these relational tensions? These tensions, according to Donald, are integral to moving towards decolonization. Perhaps, it is with the teacher candidates like James, who are open to risk and seeking difference, where productive conversations might occur about colonization, privilege, and othering, thus, reframing teacher candidates' expectations and provoking possibilities for transformation.

\section{Blake: Having the Right Stuff}

As Blake was packing, she found herself worrying about what she needed to bring to ensure she could plan effective lessons for her students. What resources would they have at her northern school? What technology would be available? Would there be Wi-Fi? Would she need to bring her own printer? Once she arrived, she was surprised - and disappointed - to find that the technology was quite behind the times and not as advanced as she'd hoped. She was also surprised by how often the students were absent. Many of her students had missed an entire week of school for "goose camp," a seasonal excursion and cultural experience where families ventured to out- 
camps to hunt the migrating geese. It was bad timing, too, because Blake had really wanted to broaden her students' worlds by showing them a live broadcast of We Day. However, due to the touchy internet and the large number of absent students, she abandoned the idea. Blake was frustrated. She was trying to engage her students and to make connections to the outside world but felt undermined in her attempts, both by the lack of resources available and by the students' absences.

In this account, we see Blake's anxiety about the potential lack of resources and access to technology that she believes are integral elements of her teaching practice. She was concerned with the stuff she thought she would need to bring, the stuff that may or may not be available once she arrived, and how all of this stuff is essential in enacting the curriculum. Blake's focus on the material aspects of instruction overshadows her curiosity about her students, or where and how they live. Her anxiety might be, in part, influenced by deficit assumptions of schools (and life) in the North - that these communities are somehow "behind" or "lacking." We also see the concomitant assumption that privileges a particular kind of knowledge (i.e., one found in purchased resources and on the internet); as well as a particular kind of teaching (i.e., one in which the teacher brings the knowledge into the classroom for students to consume). Blake appears to privilege the "school" knowledge, where "curriculum becomes an anonymous Other whose linkages to everyday life are fragile and implicit" (Pinar, 1991, p. 174). Like many new teachers, Blake has not yet understood curriculum as "a place of origin as well as destination, a ground from which intelligence can develop, and a figure for presenting new perceptions and reviewing old ones" (Pinar, 1991, p. 186). Her inattention to the students' engagements with goose camp is a missed opportunity to develop a curriculum that reflects her students' lived experiences.

Teacher candidates, often preoccupied with the "doing" of teaching (Britzman, 2003), can lack attentiveness to their students, families, and cultural practices, and to the rich curricular opportunities that emerge in particular places. As Gruenewald (2003b) states:

Places are profoundly pedagogical. That is, as centers of experience, places teach us about how the world works and how our lives fit into the spaces we occupy. Further, places make us: As occupants of particular places with particular attributes, our identity and our possibilities are shaped. (p. 621)

A place-based pedagogy orients the learner into considering and analyzing places, the people, and the relationship between these. Whereas goose camps are perceived as an "interruption" to schooling, it could have well become the curriculum - an elicitation of local events and practices to teach interdisciplinary concepts (Sobel, 2004). This kind of inquiry, where curriculum is "grounded in local issues and possibilities" (Sobel, 2004, p. 57), allows students to be knowledge co-constructors, draws on community experts and elders, and centres the relevance and importance of local cultural events, thus increasing students' engagement and regard for their community and their practices (Smith \& Sobel, 2010). By engaging the students' lived experiences, teachers can foster contextual understandings and appreciations of culture, recognize the inter-relatedness of culture and the environment, and develop a curriculum that is multidisciplinary (Gruenewald, 2008).

Further, and perhaps admirably, we see in Blake's narrative a desire to broaden her students' experiences by bringing in the "outside" world; by providing the students in a remote and isolated community with a glimpse of an urban spectacle (We Day) in which thousands of 
other students across the province participate. ${ }^{2}$ Aside from the saviour critique that could be made here, we need to also consider the ways in which a critical pedagogy of place would foster an understanding of the teacher candidates' relationship with and to curriculum, where understanding place means to understand it in relationship with others and between places (Gruenewald \& Smith, 2008, p. 149). Through a critical pedagogical engagement teacher candidates could begin developing an awareness of the relationships between the local and how these connect globally; where one could have connected the goose camp experience to the "outside" world. For example, goose camp could have become the impetus for critical considerations of injustice, drawing on historic, geographic, and ecological perspectives (Gruenewald \& Smith, 2008, p. 148). A critical pedagogy of place would foster an engagement with that place, taking into account those who live there, their relationships to that place, and what could be learned from these relationships that might inform greater understandings of local and global issues.

\section{Erin: The Politics of Place(s)}

Although Erin found the northern practicum experience difficult, she would do it again in a heartbeat. For her, it wasn't like an adventure billboard depicting glorified trailblazers; rather, it was a slow paced, pleasantly simple, and isolated life. She learned that families don't often travel far from home and don't necessarily share the same values of a formal education that would require them to leave. Some remain distrustful of the school system because of colonization, residential schools, and the trauma and fear experienced by those events that remain in the shadows. Yet, Erin found the atmosphere of the school enjoyable; it was quiet and laid back and the students were mild-mannered and kind. Now teaching in an elite urban school, Erin was trying to bridge the massive gap between the quiet yet complex reality in the North, and her private school students' experiences-driving their new mini-coopers and receiving \$10,000 allowances. Uncomfortable with her students' intolerance of the differences of others, Erin wanted to foster their understandings and openness to differences; and to help them understand their privilege and the vastly differing contexts from which people can come.

For Erin, who was apprehensive about living in the North, the experience fostered a more nuanced understanding of colonialism, the effects of residential schools, and the different world views of the people who lived there. She developed an appreciation for the quieter and simpler experiences in the North, yet also began to develop an understanding the complexities of the place. The northern practicum fostered a shift in perspective for her, a recognition of the differences of experience and new understandings of privilege. Importantly, in Erin's narrative we see that the importance of developing place-consciousness in fostering more critical ways of thinking and being. Thus, we see the potential of place-consciousness and the development of critical perspectives, where nostalgic or homogenous understandings of place and people are challenged, where criticality becomes a lens to consider how issues of race, class, and gender, for example, operates in specific - and in various - places.

Place-consciousness cultivates an awareness of the sociopolitical contexts that operate and that maintain oppression (Gruenewald, 2008). The northern practicum could foster for teacher candidates an experience of a place in which they could begin to understand the social, political, historical effects and operations of power that work to oppress and to maintain oppression. Being in different - and in this case, northern-places can create a disruption where the teacher candidates' experiences are dissimilar to their own places and also not what they had anticipated. "In the context of Aboriginal education in Canada, this unsettling takes another step in positional 
dissonance by decolonizing not just cultural location of the student teacher and their pedagogy, but also of engendering an acknowledgement of legislated implication in the Aboriginal/nonAboriginal relationship in Canada given all Canadians are treaty partners" (Scully, 2012, p. 153). We see in Erin's narrative not only a sense of being unsettled, but also a new level of understanding of our shared colonial history - a colonization that is not just historical, but that also lives in the present.

Importantly, Erin's experience also illustrates her insights about the place that she visited and the sociohistoric issues that exist there, and her desire to understand her current place - the private school in which she is now employed. A place-consciousness fosters a desire to understand one's relationship to place but can also drive teacher candidates to consider relationships between places. As Gruenewald (2003b) reminds us, "Places teach us who, what, and where we are, as well as how we might live our lives" (p. 636). Erin's place-conscious perspectives seem to foster an appreciation for socially just perspectives, as well as for critical considerations of what it means to be a teacher. Here we see the potential of place-consciousness and the ways in which it can instill "a reformulation of the school's relationship to other social institutions and people, and a reimagining of what education might be" (Smith \& Sobel, 2010, p. 29). After all, as Donald (2011) explains, it is our relationships with each other that must guide how we live and act. Donald (2011) explains, "Any knowledge we gain about the world interweaves us more complexly with these relationships and gives us life" (p. 104). In Erin's narrative, we see the effects of her northern practicum experiences on her understandings of difference and of who she wants to be as a teacher.

\section{Concluding Thoughts: Being in Relation}

Again, any "shortcomings" perceived in these depictions of the teacher candidates is not a fault of theirs alone; in large part, they reflect social and normative discourses, often a part of the settlercolonial narrative. These narratives also illustrate the deficiencies in our program and as a faculty to better prepare teacher candidates for what they will experience, and specifically, to better develop place-conscious perspectives prior to and while engaging in student $\mathrm{s}$. These deficiencies are illustrations of the ways in which the urban centeredness of our Bachelor of Education program (and likely most teacher education programs in Canada) is naturalized. Subsequently, these programs do not adequately attend to supporting non-urban teaching experiences, particularly in rural, remote, and northern communities, all of which hold a particular geographic, historic, social, and cultural importance in Canada, a country often defined, at least in part, by and through its relationship to its geography and its landscape. Thus, this critical exploration underscores the importance of place and of actively fostering a place-consciousness in Canadian teacher education (Darling \& Taylor, 2015, p. 248). Through supported northern practicum options, teacher candidates could enrich their experiences, challenge their understandings, and foster a critical awareness of the importance of the local in context with and in relation to the larger global issues and forces. Therefore, because place influences identities and possibilities for a critical understanding of the world, fostering critical consciousness could be very powerful for teacher candidates, their practicums, and their future teaching experiences.

Importantly, place-consciousness is just as important for the instructors and faculty in teacher education programs, as it is for the teacher candidates whom we aim to support. As Gruenewald (2008) reminds us, place-based education raises 'teachers' and students' sociopolitical consciousness of the cultural and institutional practices that help to maintain oppressive relationships" (p. 139-140). In the practicum option originally developed in our 
Faculty, we made a concerted effort to have faculty act as the practicum supervisors for our northern practicum teacher candidates. We chose faculty who had research, teaching and/or, professional connections with particular northern communities to be faculty advisors in those communities. In doing so, we supported both the faculty members in pursuing their work and supported the teacher candidates by providing them with a faculty advisor who had connections to and understandings of specific communities. Not only does this strategy support the faculty member and the specific teacher candidates, it can have a ripple effect in that the faculty member then has these experiences in northern communities to draw on and bring into the teacher education classes.

However, simply offering northern practicum options and including faculty in these experiences is insufficient. Both teacher candidates and teacher educators need support in learning about place-consciousness, particularly in relation to Canada's shared colonial history and in this time of Truth and Reconciliation. The discourses of settler-colonialism are pervasive and often remain naturalized in schooling, including in teacher education. Greater critical attention to place is one way to begin to engage in and challenge these often entrenched settler-colonial narratives. As Donald (2009) wisely states:

If colonialism is indeed a shared condition, then decolonization needs to be a shared endeavour. ... Aboriginal peoples and Canadians [need to] face each other across historic divides, deconstruct their shared past, and engage critically with the realization that their present and future is similarly tied together. (p. 5)

Understanding our shared condition in this place must be purposefully pursued. As seen through the teacher candidates' narratives, without supporting the development of critical placeconsciousness, simply offering northern practicums could risk reinforcing narratives of saviourism and of settler-colonial perspectives.

Finally, our understandings of place are intimately tied to the people in these places and the relationships among us and across varied places. Donald (2011) reminds that, "any knowledge we gain about the world interweaves us more complexly with these relationships and gives us life" (p. 104). Thus, a place conscious approach to teacher education could be enhanced through practicums in the North, which could foster better understandings of the myriad of relationships we find ourselves in: relationships between and among communities, between human and nonhuman life, between local and global issues, and between economic and ecological priorities - not as dualisms, but as interconnected relationships. These perspectives would help us all to better understand education as an ethical endeavour that - although situated within a particular times and places - is always in relation.

\section{Endnotes}

${ }^{1}$ The phrase, "event of place" is from D. B Massey (2005), but I originally came across in Tuck \& McKenzie (2015, p. 140). The larger quotation, I think speaks beautifully to the complicated beauty of place.

${ }^{2}$ Although a critique of We Day itself is warranted, it is beyond the scope of this paper. For a very good critical analysis of We Day, see Jefferess (2012).

\section{References}

Association of the Canadian Deans of Education (ACDE). (2010). Accord on Indigenous Education.Retrieved from 
https://www.oise.utoronto.ca/aboriginal/UserFiles/File/FoE document ACDE Accord I ndigenous Education 01-12-10-1.pdf

Battiste, M. (1998). Enabling the autumn seed: Toward a decolonized approach to Aboriginal knowledge, language and education. Canadian Journal of Native Education, 22(1), 1627.

Brandon, J. (2015). Excellent teachers for northern and remote Alberta schools. In N. Maynes \& B. E. Hatt (Eds.), The complexity of hiring, supporting, and retaining new teachers across Canada (pp. 150-168).

Canadian Association for Teacher Education. Retrieved from https://www.researchgate.net/profile/Gerald_Galway/publication/291520654 Is_teaching_still_a_viable_option_in_Atlantic_Canada/links/5726209008aee491cb3f09 21.pdf\#page $=162$

Britzman, D. P. (2003). Practice makes practice: A critical study of learning to teach (Rev. ed.). New York, NY: Suny Press.

Creswell, J. W., \& Poth, C. N. (2017). Qualitative inquiry and research design: Choosing among five approaches. ( $4^{\text {th }}$ ed.). Los Angeles, CA: Sage.

Danyluk, P., \& Sheppard, G. (2015a). Early teaching experiences in northern, remote, or First Nation, Métis and Inuit communities: Implications for initial teacher education. In L. Thomas \& M. Hirschkorn (Eds.), Change and progress in Canadian teacher education: Research on recent innovations in teacher preparation in Canada (pp. 217-250). Canadian Association for Teacher Education.

Danyluk, P., \& Sheppard, G. (2015b). Preparing bachelor of education candidates to teach in Ontario's northern, remote, First Nations, Métis and Inuit Communities. Toronto, ON: Higher Education Quality Council of Ontario.

Darling, L. F., \& Taylor, T. (2015). Rural landscapes and teacher education in Canada: Exploring the role of place-consciousness in preparing and supporting rural teachers. In T. Falkenberg (Ed.), Handbook of Canadian Research in Initial Teacher Education (pp. 245-260). Ottawa, ON: Canadian Association for Teacher Education.

Day, C., \& Gu, Q. (2010). The new lives of teachers. New York, NY: Routledge.

Donald, D. (2009). Forts, curriculum, and Indigenous métissage: Imagining decolonization of Aboriginal-Canadian relations in educational contexts. First Nations Perspectives, 2(1), $1-24$.

Donald, D. (2011). Forts, colonial frontier logics, and Aboriginal-Canadian relations: Imagining decolonizing educational philosophies in Canadian contexts. In A. A. Abdi (Ed.), Decolonizing philosophies of education (pp. 91-111). Rotterdam, NL: Sense.

Foucault, M. (2010/1972). The archaeology of knowledge. New York, NY: Random House.

Goulet, L. (2001). Two teacher s of Aboriginal students: Effective practice in sociohistorical realities. Canadian Journal of Native Education, 25(1), 68-82. 
Green, B., \& Reid, J. (2004). Teacher education for rural-regional sustainability: Changing agendas, challenging futures, chasing chimeras? Asia-Pacific Journal of Teacher Education, 32(3), 255-273.

Groenewald, T. (2004). A phenomenological research design illustrated. International Journal of Qualitative Methods, 3(1), 42-55.

Gruenewald, D. A. (2003a). The best of both worlds: A critical pedagogy of place. Educational Researcher, 32(4), 3-12.

Gruenewald, D. A. (2003b). Foundations of place: A multidisciplinary framework for placeconscious education. American Educational Research Journal, 40(3), 619-654.

Gruenewald, D. A. (2008). Place-based education: Grounding culturally responsive teaching in geographic diversity. In D. A. Gruenewald \& G. A. Smith (Eds.), Place-based education in the global age (pp. 137-153). New York, NY: Lawrence Erlbaum.

Gruenewald, D. A., \& Smith, G. A. (2008). Introduction: Making room for the local. In D. A. Gruenewald \& G. A. Smith (Eds.), Place-based education in the global age (pp. xiiixxiii). New York, NY: Lawrence Erlbaum.

Harper, H. (2000). "There is no way to prepare for this": Teaching in First Nations schools in Northern Ontario-Issues and concerns. Canadian Journal of Native Education, 24(2), 144.

Janzen, M. D., \& Cranston, J. (2015). Motivations and experiences of teachers in a northern Manitoba community. The Alberta Journal of Educational Research, 61(2), 166-183.

James, N. (2007). The use of email interviewing as a qualitative method of inquiry in educational research. British Educational Research Journal, 33(6), 963-976.

Jefferess, D. (2012). The "Me to We" social enterprise: Global education as lifestyle brand. Critical Literacy: Theories and Practices, 6(1), 18-30.

Jones, A. (2011). Rethinking the rural practicum. Online Submission. Retrieved from http://files.eric.ed.gov/fulltext/ED522823.pdf

Klassen, R. M., Foster, R. Y., Rajani, S., \& Bowman, C. (2009). Teaching in the Yukon: Exploring teachers' efficacy beliefs, stress, and job satisfaction in a remote setting. International Journal of Educational Research, 48(6), 381-394.

Kutsyuruba, B., \& Treguna, L. (2014). Curbing early-career teacher attrition: A pan-Canadian document analysis of teacher induction and mentorship programs. Canadian Journal of Educational Administration and Policy (161), 1-42.

Loeb, S., Darling-Hammond, L., \& Luczak, J. (2005). How teaching conditions predict teacher turnover in California schools. Peabody Journal of Education, 80(3), 44-70. doi: 10.1207/s15327930pje8003_4

Moustakas, C. (1994). Phenomenological research methods. Thousand Oaks, CA: Sage. 
Mueller, R., Carr-Stewart, S., Steeves, L., \& Marshall, J. (2011). Teacher recruitment and retention in select First Nations schools. in education, 17(3), 56-71. Retrieved from http://ineducation.ca/ineducation/article/view/72/554

Multamaki, S. (2008). Preservice teachers' perceptions of teaching in communities of northwestern Ontario. Unpublished thesis. Lakehead University, Thunderbay, Canada. Retrieved from http://inukshuk.lakeheadu.ca:7008/vwebv/search?searchArg= Preservice+Teacher $\mathrm{s} \% 27+$ perceptions + of + teaching + in + communities + of + northwestern + Ontario\&searchCode $=\mathrm{TKEY} \% 5 \mathrm{E}^{*} \&$ limitTo $=$ none\&recCount $=10 \&$ searchType $=1$.

Orr, D. (1992). Ecological literacy. Albany, NY: State University of New York Press.

Oskineegish, M., \& Berger, P. (2013). The role of the non-native teacher in remote First Nations communities in northern Ontario. Canadian Journal of Native Education, 36(1), 113.

Pinar, W. F. (1991). Curriculum as social psychoanalysis: On the significance of place. In J. Kincheloe \& W. F. Pinar (Eds.), Curriculum as social psychoanalysis, (pp. 165-186). Albany, NY: State of University of New York Press.

Royal Canadian Mounted Police. (2014). Report: Missing and Murdered Aboriginal Women: A National Operational Overview. Retrieved from http://www.rcmp-grc.gc.ca/en/missingand-murdered-aboriginal-women-national-operational-overview\#sec6

Scully, A. (2012). Decolonization, reinhabitation and reconciliation: Aboriginal and place-based education. Canadian Journal of Environmental Education (CJEE), 17, 148-158.

Seawright, G. (2014). Settler traditions of place: Making explicit the epistemological legacy of white supremacy and settler colonialism for place-based education. Educational Studies, $50(6), 554-572$.

Smith, G. A., \& Sobel, D. (2010). Place- and community-based education in schools. New York, NY: Routledge.

Smits, H. (2010). Introduction: The aporia of ideology and utopia-Field experiences in teacher education as peril and promise. In T. Falkenberg \& H. Smits (Eds.), Field experiences in the context of reform of Canadian teacher education programs (Vol. 1, pp. 51-66). Winnipeg, MB: Faculty of Education, University of Manitoba.

Sobel, D. (2004). Place-based education: Connecting classrooms and communities. Great Barrington, MA: Orion Press.

Talaga, T. (2017). Seven fallen feathers: Racism, death, and hard truths in a Northern city. Toronto, ON: Anansi Press.

Truth and Reconciliation Commission of Canada. (2015). Truth and Reconciliation Commission of Canada: Calls to Action. Winnipeg, MB: Retrieved from http://www.trc.ca/websites/ trcinstitution/File/2015/Findings/Calls_to_Action_English2.pdf

Tuck, E., McKenzie, M., \& McCoy, K. (2014) Land education: Indigenous, post-colonial, and decolonizing perspectives on place and environmental education research. Environmental Education Research, (20)1, 1-23, doi: 10.1080/13504622.2013.877708 
Tuck, E., \& Yang, K. W. (2014). Unbecoming claims: Pedagogies of refusal in qualitative research. Qualitative Inquiry, 20(6), 811-818.

White, S., \& Reid, J.A. (2008). Placing teachers? Sustaining rural schooling through placeconsciousness in teacher education. Journal of Research in Rural Education, 23(7), 1-11.

Williment, M. (2003). A descriptive study of teacher retention and attrition in Northern Lights School Division \#113, Saskatchewan. Saskatoon, SK: Dr. Stirling McDowell Foundation. Retrieved from http://www.mcdowellfoundation.ca/main_mcdowell/projects/research _rep/project_91.pdf

Winter, E. C., \& McEachern, W. R. (1999). Subject specialization in teacher education: An experience in a Canadian Native school. Education, 119(4), 713. 